\title{
Medicolegal
}

\section{Doctors with AIDS and the "News of the World"}

\author{
CLARE DYER
}

On Friday 6 November the High Court granted a London district health authority a permanent injunction against the News of the World, banning the newspaper from reporting the identities of two doctors undergoing treatment for acquired immune deficiency syndrome (AIDS) in one of the authority's hospitals. The injunction also restrains the newspaper from publishing, disclosing, or making use of any information from the doctor's medical records passed to a reporter, David Leslie, by a hospital employee last February. But the judge refused to order the reporter to disclose his sources as the health authority had not produced sufficient evidence that the disclosure was "necessary in the interests of justice or national security or for the prevention of disorder or crime," as required by the Contempt of Court Act 1981.

On 27 February the newspaper put the allegations to the hospital and asked for comments. The following day the health authority won an injunction, temporarily silencing the newspaper. When both parties went to court on 12 March Mr Justice Ian Kennedy refused to lift the injunction, pending the trial, which started on 2 November. Unusually, the trial was held in camera because the judge, $\mathrm{Mr}$ Justice Rose, took the view that it could not be conducted in public without disclosing the very details that the health authority was seeking to keep confidential. The 44 page judgment does not identify the doctors, the hospital treating them, or the health authority that sought the injunction. The physician who was treating them gave evidence but was not named in the judgment. The doctors, according to the judge "have carried on general practice in the United Kingdom," after having been diagnosed as suffering from AIDS. Whether or not they are still practising was not disclosed.

\section{"News of the World" guilty of contempt}

On 15 March, the Sunday after the unsuccessful application to lift the injunction, the News of the World ran an article headlined "Scandal of Docs with AIDS." The story says that the paper had put three questions to the Department of Health and Social Security, which the department refused to answer. Were any general practitioners affected with AIDS currently on duty in surgeries nation wide? Would Sir Donald Acheson hold the same views - that doctors with AIDS could carry on treating patients-in the case of a doctor practising gynaecology? Were there any doctors suffering from AIDS as a result of homosexual relationships? The story suggested that failure to reply constituted a cover up.

Mr Justice Rose found the paper to be in contempt of court in publishing the article and imposed a fine of $£ 10000$. The injunction forbade the newspaper to make use of the confidential information, and the judge said that it was plain that the editor had used the information in drafting the questions. It would be a remarkable coincidence, he added, if without using the information, the

\section{London NW1}

CLARE DYER, BA, BLs, legal correspondent suggested line of questioning had succeeded in highlighting matters revealed by the confidential information.

\section{The law of confidence}

In seeking the injunction the health authority relied on the law of confidence, the same law that has been used by the government to suppress publication of the Spycatcher revelations and by the royal family to silence ex-servants tempted to sell their secrets to the tabloids. Employees owe a duty to their employers not to disclose confidential information acquired in the course of their employment. But the courts may allow the information to be published if it is in the public interest that it should be disclosed. The chief issue in this case was whether the public interest justified the News of the World publishing the information that two identified practising doctors were being treated for AIDS at an identified hospital, information which had been disclosed in breach of contract and in breach of a duty of confidence.

The public interest defence goes back to a phrase used in a midnineteenth century case: "There is no confidence as to the disclosure of an iniquity." The extent of the defence has been debated in several recent cases, and in a 1968 case Lord Denning commented: "I do not look upon the word 'iniquity' as establishing a principle. It is merely an instance of just cause or excuse for breaking confidence. There are some things which may be required to be disclosed in the public interest, in which event no confidence can be prayed in aid to keep them secret." In a 1974 case involving Private Eye the court gave a comprehensive definition: "The defence of public interest clearly covers... disclosure which ... must be disclosure in the public interest, of matters carried out or contemplated, in breach of the country's security, or in breach of law, including statutory duty, fraud, or otherwise destructive of the country or its people, including matters medically dangerous to the public; and doubtless other misdeeds of similar gravity."

In a 1984 case, which involved alleged breaches of Jockey Club rules, Sir John Donaldson stated: "There is a countervailing public interest in exposing conduct which involves a breach of the law or which is 'antisocial'." In the Lion Intoximeter case, also in 1984, in which a newspaper was allowed to publish confidential company documents which cast doubt on the accuracy of the intoximeter, Lord Justice Griffiths said: "I can see no reason why this defence should be limited to cases in which there has been wrongdoing on the part of the plaintiffs." He went on to say: "When the press raise the defence of public interest, the court must appraise it critically, but if convinced that a strong case has been made out, the press should be free to publish, leaving the plaintiff to his remedy in damages."

In the present case Mr Justice Rose summed up the balancing act he had to perform as follows: "On the one hand there are the public interests in having a free press and an informed public debate; on the other it is in the public interest that actual or potential AIDS sufferers should be able to resort to hospitals without fear of this being revealed, and those owing duties of confidence in their employment should be loyal and should not disclose confidential matters and that, prima facie, no one should be allowed to use 
information extracted in breach of confidence from hospital records even if disclosure of the particular information may not give rise to immediately apparent harm."

\section{Expert witnesses}

Expert witnesses for the health authority-Sir Donald Acheson, chief medical officer for the DHSS and a member of the General Medical Council; Dr Donald Jeffries, a clinical virologist at St Mary's Hospital; and Professor Michael Adler, professor of genitourinary medicine at Middlesex Hospital, as well as the unnamed physician who treated the two doctors-gave evidence about the risk to patients from general practitioners with AIDS or infection with human immunodeficiency virus (HIV). Sir Donald told the court that there was no prohibition on infected doctors practising. In his opinion, the risk to patients was "slightly more than negligible," but the way to cope with the risk was to encourage them to consult a doctor who could advise them how to minimise the risk. Dr Jeffries said that the extremely small danger to patients from the transfer of body fluids was reduced, by education and training, to non-existence. Professor Adler said that there was nothing to be gained by a patient in knowing that his doctor was infected because he was not at risk. A doctor with dementia was the same as an alcoholic in terms of being a potential threat to his patients through lack of judgment, not infection, and proper counselling must be given and followed.

For the defendant, Dr Robert Levy, a leading American AIDS specialist, gave evidence that there was no general restriction on infected doctors practising in America. Monitoring was carried out on a case by case basis, particularly for early signs of dementia that might affect professional performance. Dr Lesley Kay, a haematologist, said that HIV was able to survive outside the body, that transmission might occur in saliva, and that gloves were holed in a considerable percentage of surgical procedures.

\section{The judgment}

Giving judgment, Mr Justice Rose said that confidentiality was of paramount importance to AIDS patients, including doctors. If patients had grounds for believing that it might be breached they would be reluctant to come forward for and to continue with treatment and, in particular, counselling. If treatment was not provided or continued the individual would be deprived of its benefit and the public would be likely to suffer from an increase in the rate of spread of the disease. The preservation of confidentiality was therefore in the public interest. The public interest in freedom of the press and in knowing the information which the newspaper sought to publish was substantially outweighed by the public interest in loyalty and confidentiality both generally and with particular reference to AIDS patients' hospital records. There had been no misconduct by the plaintiffs, the health authority. The records of hospital patients, particularly those suffering from this appalling condition, should be as confidential as the court could properly keep them. Despite the injunction, all the evidence showed that a wide ranging public debate about AIDS generally and its effect on doctors was already taking place among doctors, within and without the BMA, in medical journals, and newspapers.

Further fuel was added to the debate last weekend, when the Mail on Sunday revealed the death from AIDS of a consultant working in the renal unit of The London Hospital. An attempt was made to stop publication of the name, but the newspaper was able to go ahead because the information did not appear to have been obtained in breach of confidence. Reaction to the stories shows that public concern about doctors infected with HIV has not been dispelled by the experts' reassurances. Sir Donald Acheson, chief medical officer, and Sir John Walton, president of the General Medical Council, both believe that doctors who discover that they are infected have "a duty to seek confidential advice on what steps they should take to protect their patients." Presumably the council will be amending its professional conduct code accordingly.

\section{Medicine and the Media}

\footnotetext{
$\mathrm{T}$ HE News of the World, The Times, and Today are all owned by the same group, and only the naive would expect The Times or Today to support the High Court's decision to stop the News of the World from publishing its revelations about two doctors with the acquired immune deficiency syndrome (AIDS). What is more disturbing is that Today should launch a vitriolic crusade against the Chief Medical Officer, Sir Donald Acheson, and that The Times's medical correspondent, Dr Thomas Stuttaford, should support the News of the World in an article that is a triumph of tortured logic.

Today, which is edited by David Montgomery (who until recently edited the News of the World), interprets the whole affair as an attempt by doctors to cover up for each other. It condemns "one law for doctors and another for the patients," quite failing to understand that Sir Donald and others are arguing strongly for one law for allthe law that confidentiality will be maintained. The newspaper does not appreciate that once confidentiality has gone AIDS will be driven underground and we will have less chance of countering the epidemic. Its ignorance does not, however, stop Today calling for Sir Donald's resignation and accusing him of "gross hypocrisy and dereliction of duty" for calling editors together some months ago to ask them to publicise AIDS and then "a few months later... appearing on behalf of the health authority which is seeking to hush up the whole matter." The editor of Today is so much a popular journalist that he seems to imagine that the rest of the world
}

subscribes to the bankrupt philosophy that any publicity is good publicity. Sir Donald has shown no hypocrisy and has, indeed, probably done more than any other man in the country to counteract the AIDS epidemic in Britain.

Dr Stuttaford in his piece in The Times (12 November, p 16) attempts to argue that the High Court concentrated on the risk of the doctors infecting patients and missed the point that doctors with AIDS may be demented and hence a danger to their patients. His first mistake was to rely on press reports of the case and fail to read the judgment. In fact, the 44 pages explore thoroughly the question of the dangers of the doctors being demented.

Next Dr Stuttaford says that it is inconsistent of the medical establishment to take steps to stop doctors with alcohol problems practising when it is taking "no similar steps to prevent those doctors who catch a disease of which dementia forms such a prominent part from taking life and death decisions." He does not understand that the systems set up apply to doctors who have any sort of sickness that reduces their competence.

But Dr Stuttaford is well aware that for every doctor demented through AIDS (and we do not know if there is any such doctor in Britain) there must be hundreds demented through age and alcohol, and in attempting to get round this canyon in his argument he performs his most miraculous arabesque. Without a shred of evidence he argues that "on the whole it seems to be less dangerous 